\title{
The Reality of Using Darsak Platform and Its Obstacles By The Teachers of Primary School in Southern Amman Schools in Light of The Corona Pandemic COVID-19
}

\author{
Dr. Fawwaz Hasan Shehada, Ph.D. Curriculum and Teaching Methods \\ Doaa Mahmoud Khalil, Information and Communication Technology in Education \\ Faisal Shawkat Alrawajfah, Information and Communication Technology in Education
}

\begin{abstract}
This study aimed to identify the reality of using Darsak platform and its obstacles By the Teachers Of primary school in southern Amman schools in Light of the Corona pandemic COVID-19. The study used the descriptive survey approach, and to collect data, a questionnaire was developed on the reality of using For Darsak platform and its obstacles By the Teachers Of primary school it's consisted of (53) items, and their validity and reliability were confirmed. The questionnaire was distributed to a sample of (143) male and female teachers in schools in southern Amman. The results of the study showed that the responses of the study sample were in agreement with a medium degree to the reality of using Darsak platform by the Teachers Of primary school in southern Amman schools in Light of the Corona pandemic COVID-19 from there point of view. The most important recommendations of the study was to encourage primary school teachers to use Darsak platform to a large extent, and to spread the importance of e-learning among the elements of the educational process and to parents.
\end{abstract}

Keywords:

Darsak platform, Teachers Of primary, Corona pandemic COVID-19.

Article Received: 18 October 2020, Revised: 3 November 2020, Accepted: 24 December 2020

\section{Introduction}

In recent years, the world has shifted with rapid technological and information developments, and the appetite for different cultures, Which requires those responsible for educational institutions to make education more effective; And following up on all global changes, To be aware of these changes, developments and challenges; In light of global transfers and educational development policies that took many forms, including professional development for teachers, e-learning, distance learning and other methods of development, which is reflected in the positive use of them.

Corona pandemic COVID-19 Create great pressure on various areas of life, most notably the educational aspect (Unesco Education, 2020), Therefore, resorting to distance learning was the fastest emergency solution in order to preserve the study, and the spread of the virus constituted a burden on parents in searching for the means available according to their capabilities in order for their children to continue receiving education (Christopher, 2020), While (Adeniran, 2020) indicated that the Coronavirus crisis has affected the education sector; As educational institutions such as schools and universities were pushed to close to reduce the spread of the virus, which raised great concern among those affiliated with this sector (Bozkurt et al, 2020).

The last recent years have witnessed a great development in technological innovations related to education, starting from computer education (Parekh, 2006), to the use of the Internet in the educational process and on to elearning, which is one of the types of education (Martirosyan, et al., 2017). The progress in the subject of information technology has led to the availability of many technological methods (Murphy et al., 2019), and thus the distance between the learner and the teacher has diminished, which required an urgent need to 
develop methods and skills for learning and teaching to bring the learner to self-acquisition of information (Yang et al., 2020), And as Hoban mentioned that the educational material is provided to the learner in the shortest time and with the least effort, depending on the tools of technology and the methods it has developed (Gill, 2019), This system is mainly based on the existence of a digital electronic environment that deals with the decisions taken by electronic networks and provides all the guidance and direction the learner needs (Warner et al., 2018). E-learning has proven successful, which has made many educational institutions adopt the so-called educational platforms (Abdel-Naim, 2016).

Al-Juhani (2016) indicates that electronic learning platforms are at the forefront of technologies that are witnessing more adoption in teaching. Because of the pleasure it brings to the teaching and learning processes; And it increases (Carlos \& Infante, 2015) that this pushes the learner to interact with the content presented through it, and interact with his peers and mentor, in addition to involving him in many tasks that develop his skills (Farah, 2015).

The Darsak platform is one of the most prominent platforms that have appeared recently; It is a free Jordanian distance learning platform, provided to school students from the first grade to the second grade of secondary school. It provides educational lessons through video clips that are organized according to the Jordanian education curriculum, provided by a distinguished group of male and female teachers to make it easier for students to continue their learning and follow up on their study materials. Every student can use the platform remotely with ease, as every student can choose the educational material within the weekly schedule of lessons (Jordanian Ministry of Education, 2019).

The Darsak platform was established with the aim of covering all educational lessons from all courses and grades and according to the Jordanian education curriculum according to plans before the outbreak of the Corona Covid-19 pandemic. It was the appropriate solution to avoid any obstacle in the progress of the school study. The platform provides lessons in the form of video clips throughout the week, and this platform also links educational service providers with the Jordanian Ministry of Education. The first group works to provide educational video lessons according to what is decided by the Ministry's educational plan of lessons for each class and for each subject and throughout the week, these lessons are produced by a high technology that simulates the classroom in terms of the teacher's presence in voice and image (Jordanian Ministry of Education, 2019).

Darsak platform works by preparing the day for the study completely before its time comes, so that all tables are reviewed more than once by more than one team, within an integrated workshop to ensure that the lessons are free from any error, and when the student starts studying, he enters the platform to receive his scheduled lessons every On a day, which is presented to him and from more than one service provider that completes the distance learning process, and automatically the materials that you will teach for this day - which vary from day to day - will appear to the student, the videos devoted to this day and this for each material and from more than one service provider in most cases. The platform enables the student to re-follow the scheduled lessons during the day and 24 hours (The Comprehensive Guide to Darsak Platform, 2019).

The student must be aware of the most important points about the lesson platform and the mechanism for displaying and distributing lessons, as lessons are presented for grades from primary to secondary in all its branches on the platform in addition to showing them on Jordanian TV channels. With regard to the grades from the first basic to the first secondary in all its branches, all the lessons under the basic subjects are covered, namely: "Arabic language, English language, science in its branches, and mathematics". All lessons are offered for the second year of secondary school of science in all 
its branches, in addition to other subjects for Arabic, English, mathematics and vocational education branches, browsing between the hours of six in the morning and four in the afternoon is free of charge. During the presentation of the educational content, the teacher supports his explanation with practical examples that help in communicating the idea to the student and clarifying the concepts and skills presented in the lesson. In the event that lessons are missed or the Internet is cut off, the student can re-follow the missed lessons through the channels: Darsak 1, Darsak 2, and the Sports Channel. After four in the afternoon, the student will be able to follow today's lessons and lessons until the next day (The Comprehensive Guide to Darsak Platform, 2019).

The educational platforms in general and the Darsak platform in particular are exposed to many obstacles, such as the weakness of the infrastructure in terms of the availability of devices and tools to help establish the platforms, the lack of knowledge of some students in the skills of using modern technologies such as computers and browsing through the Internet, the lack of conviction of some in the use of modern teaching techniques, and the difficulty of communication. Sometimes on the Internet (Distance Learning System, 2019).

Through the rapid and successive developments of technology in the digital age, educational institutions have resorted to increasing interest in their teachers, developing their capabilities, upgrading their levels and raising their professional competencies (Singh, \& Upadhya, 2008), in order to carry out the various tasks that are due to them, following up all that is new in the field Their work, stressing the necessity and importance of the quality of the educational performance of the teacher of the present and future times as a result (Buzzetto, 2012). The teacher is one of the most important elements of a successful educational process, as he plays the most important role in the process of transferring knowledge, skills, information and experience to students and makes them able to find solutions to all the difficulties they face in the future (Elis \& Goodyear, 2010), The technological development has become imperative to change the traditional teacher roles that focused on indoctrination, and consider him the main source of information, to new roles that are compatible with the changes of the digital age in a way that enables students to acquire new skills that help them to fulfill the roles and responsibilities (Zhang, 2017) and so that the teacher can provide Distinguished quality education commensurate with the needs of this era as one of the important engines in the educational process through these modern technologies (Vandenbroucke, et al, 2018).

Therefore, it is the teacher's responsibility to diversify his methods to cover different needs. Concentrating on speaking on his part throughout the course of the educational session may be appropriate for the audiences, but it is tedious for the visual and the dynamics (Al Maliki, 2010. Here, the teacher needs to choose the appropriate programs and applications to prepare a "combination" of educational materials in line with different styles. This requires the teacher to acquire skills that enable him to interact positively with the quality of education imposed by the digital age and educational platforms, in order to be able to understand the sciences of the age and its continuously evolving technologies (Saini, 2014). The teacher can use it in the educational process, presenting the educational material in a distinct way, in addition to having appropriate teaching and evaluation strategies to be an effective professional teacher capable of dealing with digital time education (Anderson, 2008).

Many literature and studies have pointed to a failure to provide teachers in general with the competencies and skills they need in the digital age, such as a study (Ibrahim, Adzraai, Sueb \& Dalim, 2019) which stated that teacher education programs are insufficient to provide future teachers with the necessary skills for them to teach in schools, and study Abualrob (2019), which indicated that teachers have a role in 
enhancing the competencies and skills of their students in the twenty-first century, which is still below expectations, as their performance in terms of training their students in the skills they need in this century did not even reach the desired level (Caruth, 2013).

Al-Shareef (2020) study aimed to identifying the reality of University student's attitudes towards to use of digital platforms in education. The study used the descriptive approach. The research tool was: a measure of trends towards the use of digital platforms in education. The study sample consisted of (120) students of the faculty of Education- Taibah University. The results of the study are the existence of statistically significant differences due to the impact of sex, in faver of males, and the absence of statistically significant differences due to the effect of the study place.

Al-Maliki \& Daghestani (2020) study aimed to identify the role of e-learning platforms in the professional development of kindergarten teachers and the obstacles to their use in education. It adopted the descriptive survey method. It covered a sample of (205) teachers in the public kindergartens affiliated to Badieaa Office, Education Department in Riyadh. Results revealed that utilizing e-learning platforms was rated $(87.2 \%)$ when providing flexible learning environments and many methods of information representation. The obstacles that hindered the use of e-learning platforms were rated (78.2\%), including the lack of financial resources, poor Internet connection, multitude of supervisory tasks and roles, and poor training programs. Furthermore, the participants strongly agreed (87\%) on the "means of professional development of kindergarten teachers when using e-learning platforms" domain, such as transferring expertise among teachers, activating professional discussion and experience sharing, and providing adequate equipment.

Al-Shawarbeh (2019) study aimed at identifying the degree to which postgraduate students in private Jordanian universities use electronic educational platforms and the degree of their attitudes towards it. As the study adopted the descriptive survey approach, the study sample consisted of (302) male and female students, and to achieve the objectives of the study, the study used a questionnaire, and the results showed that the degree of use of graduate students was high, and the degree of their attitudes towards electronic educational platforms was highly positive.

Al-Rashidi \& Brahim (2019) study aimed to identify the reality and obstacles of the use of computer teachers for educational platforms in teaching. To achieve the objectives of the study, the researcher used descriptive analytical method and adopted the questionnaire to collect data and after verifying the validity of the questionnaire, the researcher distributed it electronically to the study community, a total number of 780 teachers received the questionnaire, and the number of retrieved and analyzable questionnaires were 70 . The results of the study showed that the study community is going with reality of the use of electronic educational platforms by the teachers in the field. And the use of electronic educational platforms in teaching mostly appears during classes, followed by the use related to students' skills. It also revealed that the main obstacles faced by computer teachers in applying the electronic educational platforms for teaching were obstacles related to school administration followed by the obstacles related to curriculum followed by the obstacles related to the teachers and finally the obstacles related to the students.

Alragbi (2019) article aimed on use of massive open online courses (MOOCs) as an electronic training platform for the professional development of science teachers in Jeddah. The researcher used the semiexperimental approach in a one group design. The experiment was applied to the basic sample of research (30) education east Jeddah girls, who received the active learning course through direct training and they were randomly selected unintentionally, The researcher used a questioner to measure the 
sample satisfaction (MOOCS) as a platform for distance training, consisting of (48) paragraph. The study reached several results, the most important of which are: MOOCS achieved an efficiency level in the results of the achievement test with an average of (5.17) score for pre-test compared to (19.63) in the post-test. This means that the size of the impact is great for the use of open source electronic courses (MOOCs) in the professional development of science teachers in Jeddah.

Al-Anezi (2017) study aims the Learning about the online learning platform Edmodo and identifying its applications and advantages in contemporary teaching and learning, Identifying the opinions and views of mathematics and computer students at the College of Basic Education in Kuwait about the use of the online learning platform Edmodo in the teaching/learning process. The field study in which a questionnaire that has a 3-point Likert scale format is administered to a representative randomly selected sample involving 200 mathematics and computer students enrolled for the first term of the academic year 2015/2016 at the College of Basic Education in Kuwait. - Analysis of data using SPSS, version 19 to get the results and come up with the final recommendations and suggestions.

Durak (2017) conducted a study aimed at presenting the results of content analysis in master's theses that were conducted in the field of distance learning at the higher education level in Turkey between 1986 and 2015, the qualitative approach was used, and the study sample consisted of (285) master's theses for Knowing the trends towards distance learning, and the results showed that the most common academic discipline is education and training, and it was also noticed that the most common and used word was distance education, and the results also showed that trends towards distance learning were positive in the majority of the messages analyzed except for (49) The trends are not positive.

Bayeck (2016) conducted a study aimed at identifying the motivations of many students enrolled in an online open online course in the US. The study used the descriptive approach, and a questionnaire was used to achieve the aim of the study. The study sample consisted of (655) male and female students. The most prominent results showed that the number of female students exceeds the number of male students, and that most of the students enrolled in it are due to the love of sharing with a friend in these courses, and that the pursuit of education and professional development are the main drivers towards participating in (MOOCs) courses.

Al-Dossary's (2016) study aimed to reveal the reality of the use of educational platforms by faculty members in teaching English at King Saud University and the obstacles to their use. The study used the descriptive approach, and two questionnaires were used as a tool to achieve the goal of the study, the first to reveal the reality of use and the second to reveal obstacles to using educational platforms in teaching English. The sample of the study consisted of (70) faculty members who were deliberately chosen, and the results of the study showed that the degrees of the faculty members 'use of educational platforms in teaching English are medium, in addition to the obstacles that the faculty members use of electronic educational platforms also came with a moderate degree on the tool. As a whole.

The previous studies varied in terms of the goal, some of them indicated the identification of the reality of using and employing educational platforms in education, such as the study of the Sharif (2020), the study of the Shawarah (2019), the study of Al-Rashidi and Brahim (2019) and the study of Al-Dossary (2016). Study (Durak, 2017) as for the current study, it aimed to discover the reality of using Darsak platform in the primary stage in schools in southern Amman in light of the Corona pandemic. It also varied in terms of the tool used, as the current study agreed in terms of using the questionnaire as a tool with the study of each of the studies, such as the Sharif study (2020), the Shawarba study (2019), the Rashidi 
and Ibrahim study (2019), and the Dossari study (2016).

The current study benefited from previous studies in presenting and enriching the theoretical literature as it was used in preparing the study tool of the reality of using Darsak platform and its obstacles By the Teachers Of primary school in southern Amman schools in Light of the Corona pandemic COVID-19, To achieve its goals, and in determining the methodology used, and to interpret and discuss the results.

The current study was distinguished from related studies as it was the first study - within the limits of the researchers 'knowledge - which aimed to reality of using Darsak platform and its obstacles By the Teachers Of primary school in southern Amman schools in Light of the Corona pandemic COVID-19.

\section{The study Problem}

With technological advancements and the tremendous technological revolution that the world is witnessing in various fields of life, especially the educational process. Modern theories in education have changed the perception of the role of the teacher, and the traditional pattern of interaction that prevailed for long periods of time has changed, so the teacher has tasks other than indoctrination and delivery. Teachers may feel a sense of anxiety about their teaching skills, especially about their ability to integrate technology into their classrooms to meet the needs of their students and improve their learning.

At the beginning of the Corona pandemic, school closures were necessary. As a defense of the pandemic, the Jordanian Ministry of Education found itself in a difficult test, testing its readiness to manage this crisis. The Ministry, within the harsh conditions imposed by the quarantine procedures, made great efforts to continue the learning process, and within a record period of time it was able to come up with an electronic platform that contains video lessons for most school materials in addition to television broadcasts. Because of the pandemic, schools were closed, and learning became behind the screens of smart devices to follow the lessons broadcast by Darsak platform. The Ministry promoted new Darsak platform on the grounds that it represents a qualitative leap from its predecessor in terms of the quality of educational content and the availability of interaction between the student and the teacher in a way that qualifies it to fully rely on it.

And in the endeavor of countries and the world towards providing smart and fast solutions to all the changes that occur in the world due to the Corona virus, and to provide solutions to cover the shortage that may affect the educational system in schools, but a country like Jordan; Small in size, population, capabilities and material resources, it was able to advance its human capabilities and develop logical, scientific and technical solutions to ensure the continuation of education, so it created Darsak platform, so it became necessary with it to integrate technology fields into educational curricula, to cope with the challenges surrounding it.

Today, the primary school teacher is required to be of quality and efficiency, to be in line with the great technological renaissance the world is witnessing in the field of teaching and transfer of knowledge and culture, and to realize that one of his new tasks is to be a guide, facilitator and assistant for students to learn by themselves. So researchers direct to study this topic. The study problem is determined by the following questions:

Question one: What is the reality of using Darsak platform by the Teachers Of primary school in southern Amman schools in Light of the Corona pandemic COVID-19? This question is divided into the following subquestions:

- What is the degree of using Darsak platform By the Teachers Of primary school in southern Amman schools in Light of the Corona pandemic COVID19 from there point of view? 
- What is the obstacles of using Darsak platform By the Teachers Of primary school in southern Amman schools in Light of the Corona pandemic COVID19 from there point of view?

- What is the obstacles of using Darsak platform By the students of primary school in southern Amman schools in Light of the Corona pandemic COVID19 from there teachers' point of view?

Question two: Are there any statistically significant differences at $(\alpha \leq 0.05)$ in the reality of teachers 'use of a Darsak platform in schools in southern Amman through Covied-19 due to variables (gender, experience, teacher taking courses)?

\section{Objectives of the study}

This study aimed to know the reality of using Darsak platform by the Teachers Of primary school in southern Amman schools in Light of the Corona pandemic COVID-19, through Knowing the degree of using Darsak platform By the Teachers, and the obstacles of using it By the Teachers and students, due to variables (gender, experience, teacher taking courses).

\section{Significance of the study}

This current study is about to be represented from two sides and they are the theoretical aspect and practical aspect.

theoretical aspect: The subject of the study is one of the modern topics in which the theoretical literature contained in it can add new knowledge to researchers, and may provide the Arab library with a new theoretical framework on educational platforms in light of the Corona pandemic, and may benefit those interested in distance learning and the results of its application. It may also represent a helpful reference for those looking for educational platforms in general and Darsak platform, especially in learning, in addition to that the research may contribute to the attention of officials in the Ministry of Education about the impact of educational platforms on developing self-learning skills, which may encourage and facilitate ways to benefit from them to raise the efficiency of education and reduce the burdens Facing the educational process.

Practical aspect: Guiding the stakeholders about the reality of using the Darsak platform in the primary stage in schools in southern Amman in light of the Corona pandemic in the educational process, and assisting decision-makers in the educational field and future planners. The results of this study may benefit the Ministry of Education in improving the performance of the education system through the Darsak platform, developing human cadres and material capabilities, and developing future plans for elearning. The importance of the current study can also be taken advantage of as it keeps pace with a realistic phenomenon, which is the spread of the Coronavirus.

\section{Definition of terms}

The following terms were defined conceptually and operationally:

The reality of using primary school teachers: it is procedurally defined by the total grade the teacher obtained on the tool related to the reality of primary school teachers 'use of your lesson platform in schools in southern Amman in light of the Corona pandemic.

Darsak platform: It is a free Jordanian platform for distance learning that provides school students from grade one to the second grade of secondary school with educational lessons through video clips organized and scheduled according to the Jordanian education curriculum, provided by a distinguished group of teachers to make it easier for students to continue their learning, and follow up their study materials.

It is defined as a procedurally influencing strategy between the teacher and his students, for distance learning that seeks to communicate between the teacher and students. Students watch educational videos using audio-visual technologies 


\section{Limitations and Delimitation of the study}

The study sample was on a group of primary school teachers in south Amman schools for the first semester of the 2020/2021 academic year, and on the validity and reliability of the study tool and the accuracy and objectivity of the respondents 'response, and its results are only generalized to the same community from which the sample was withdrawn and other similar communities.

\section{Methodology}

\section{Research Methodology}

A quantitative (descriptive surveying one) research method was used as the appropriate method for this study, and one questionnaire was used applied to collect data, after assuring their validity and reliability.

\section{The population of the study}

The population of the study consisted of all male and female teachers in South Amman Schools in Jordan. Their total number was (972) male and female teachers.

\section{The sample of the study}

The sample subjects were (143) male and female teachers were selected through a random sample. The size of the sample was determined after returning to the table of determining the sample size of the population that was prepared by Krejcie and Morgan (1970).

Table (1) the distribution of the sample subjects according to the variables

\begin{tabular}{|c|c|c|c|c|}
\hline Number & variables & Types & Frequency & Percent \\
\hline \multirow[t]{3}{*}{1} & \multirow[t]{3}{*}{$\operatorname{sex}$} & Male & 82 & 57.3 \\
\hline & & Female & 61 & 42.7 \\
\hline & & Total & 143 & 100.0 \\
\hline \multirow[t]{4}{*}{2} & \multirow[t]{4}{*}{ Experience } & Less than 5 years & 57 & 39.9 \\
\hline & & $(5-10)$ years & 39 & 27.2 \\
\hline & & More than 10 years & 47 & 32.2 \\
\hline & & Total & 143 & 100.0 \\
\hline \multirow[t]{3}{*}{3} & \multirow[t]{3}{*}{ taking teacher courses } & Yes & 65 & 45.5 \\
\hline & & No & 75 & 54.5 \\
\hline & & Total & 143 & 100.0 \\
\hline
\end{tabular}

\section{The instrument of the study}

The researchers adopted one instrument to collect data which is a self-administered questionnaire and it consisted of (53) questions to identify the reality of using Darsak platform and its obstacles By the Teachers Of primary school in southern Amman schools in Light of the Corona pandemic COVID-19 consists of three parts: (teacher's using of Darsak platform in preparing electronic content and follow-up students, the obstacles encountered by teachers on the Darsak platform and the obstacles encountered by the student on the Darsak platform), This is after reviewing the platform, benefiting from the opinions of educational experts, supervisors and school directors, and using some literature and previous studies related to the subject of the study conducted in this field, such as the Al-Shareef Study (2020) and the Al-Shawarbeh (2019).

By applying Likert's five-step ladder: (very high, high, medium, low, very low).

\section{The validity of the instrument}

Validity refers to the ability of the instrument to measure what was, To make sure of the face validity of the instrument, the researchers distributed copies of the questionnaire to arbitrators, to judge the face and content validity of the items,

The correlation coefficients of the paragraphs of 
the questionnaire were calculated with the total

degree as shown in Table (2):

Table (2) Correlation coefficients of the paragraphs of the study tool with the overall degree of the tool

\begin{tabular}{|c|c|c|c|c|c|c|c|c|c|}
\hline No. & $\begin{array}{c}\text { Correlation } \\
\text { coefficient }\end{array}$ & No. & $\begin{array}{c}\text { Correlation } \\
\text { coefficient }\end{array}$ & No. & $\begin{array}{c}\text { Correlation } \\
\text { coefficient }\end{array}$ & No. & $\begin{array}{c}\text { Correlation } \\
\text { coefficient }\end{array}$ & No. & $\begin{array}{c}\text { Correlation } \\
\text { coefficient }\end{array}$ \\
\hline 1 & 0.39 & 12 & 0.44 & 23 & 0.45 & 34 & 0.43 & 45 & 0.49 \\
\hline 2 & 0.47 & 13 & 0.43 & 24 & 0.63 & 35 & 0.35 & 46 & 0.43 \\
\hline 3 & 0.67 & 14 & 0.54 & 25 & 0.54 & 36 & 0.36 & 47 & 0.44 \\
\hline 4 & 0.52 & 15 & 0.43 & 26 & 0.55 & 37 & 0.42 & 48 & 0.73 \\
\hline 5 & 0.31 & 16 & 0.39 & 27 & 0.30 & 38 & 0.36 & 49 & 0.66 \\
\hline 6 & 0.63 & 17 & 0.62 & 28 & 0.38 & 39 & 0.31 & 50 & 0.53 \\
\hline 7 & 0.41 & 18 & 0.60 & 29 & 0.34 & 40 & 0.52 & 51 & 0.65 \\
\hline 8 & 0.34 & 19 & 0.54 & 30 & 0.39 & 41 & 0.59 & 52 & 0.33 \\
\hline 9 & 0.56 & 20 & 0.52 & 31 & 0.36 & 42 & 0.69 & 53 & 0.35 \\
\hline 10 & 0.66 & 21 & 0.43 & 32 & 0.34 & 43 & 0.43 & & \\
\hline 11 & 0.37 & 22 & 0.70 & 33 & 0.32 & 44 & 0.39 & & \\
\hline
\end{tabular}

\section{The stability of the study tool}

To ensure the stability of the study tool the test-retest method was checked by applying the scale, and re-applying it after two weeks to a group outside the study sample consisting of (30), and then the Pearson correlation coefficient was calculated between their estimates both times it was $(0.74-0.85)$.

The stability coefficient was also calculated by the method of internal consistency according to the Cronbach alpha equation it was (0.71-0.89), and the stability of the tool and all the standards after distributed it again, and these values were considered appropriate for the purposes of this study.

\section{Data analysis}

To find out the reality of using Darsak platform and its obstacles By the Teachers Of primary school in southern Amman schools in Light of the Corona pandemic COVID-19, the following formula was used:

Upper unit - lower unit / Number of categories

Therefore the scale unit $5-1 / 3=1.33$ the range
Table (3): Distribution categories

\begin{tabular}{|c|c|}
\hline Description & Term \\
\hline $1.00-2.33$ & Low \\
\hline $2.34-3.67$ & Moderate \\
\hline $3.68-5$ & High \\
\hline
\end{tabular}

\section{Statistical treatment}

- $\quad$ Data were processed via SPSS.

- $\quad$ To answer the questions, arithmetic mean and standard deviations were used.

- $\quad$ Using the Cronbach-alpha equation; to find the internal consistency coefficient of the study tool.

- $\quad$ Using 3 Way ANOVA, for variables, also used.

\section{Study Procedures}

The researchers adopted the following procedures in implementing the study:

- $\quad$ Reviewing the related literature and relevant studies on the subject of the study.

- $\quad$ Designing the tool of the study and presenting it on an experienced group of judges whose remarks were taken into consideration.

- $\quad$ Assigning study sample

- Distributing the questionnaires to the sample of the study.

Collecting data from the collected sample. 
Exporting data to the computer using SPSS program.

- $\quad$ Presenting results according to the order of study questions.

Discussing the results.

Suggesting recommendations.

\section{Study Results and Discussion}

This part presents the findings of the study, in light of its questions, as the following:

The first question: What is the reality of teachers 'use of a Darsak platform in schools in southern Amman through Covied-19 from the teachers' point of view?

For answering this question, the next subquestions have been answered as follows:

- What is the degree of teacher's using of Darsak platform in preparing electronic content and follow-up students?

In answering this question, arithmetic means and standard deviations, ranks and the level for the degree of teacher's using of Darsak platform in preparing electronic content and follow-up students, were elicited and calculated as presented in the following table:

Table (4) Arithmetic means and standard deviations of the for the items of the degree section of the "teacher's using of Darsak platform in preparing electronic content and follow-up students", and its total grade

\begin{tabular}{|c|l|c|c|c|c|}
\hline No. & \multicolumn{1}{|c|}{ Item } & Mean & $\begin{array}{c}\text { Sta. } \\
\text { Deviation }\end{array}$ & Rank & Level \\
\hline 1 & $\begin{array}{l}\text { Darsak platform enables me to produce lessons } \\
\text { continuously. }\end{array}$ & 2.83 & 1.18 & 7 & Medium \\
\hline 2 & $\begin{array}{l}\text { Darsak platform is suitable for displaying the } \\
\text { course content. }\end{array}$ & 2.90 & 1.11 & 5 & Medium \\
\hline 3 & $\begin{array}{l}\text { Darsak platform enables me to properly plan } \\
\text { my lesson. }\end{array}$ & 2.85 & 1.14 & 6 & Medium \\
\hline 4 & I can use Darsak platform perfectly. & 3.12 & 1.15 & 2 & Medium \\
\hline 5 & $\begin{array}{l}\text { Darsak platform enables me to use the } \\
\text { suspense in presenting the educational material. }\end{array}$ & 2.43 & 1.12 & 13 & Medium \\
\hline 6 & $\begin{array}{l}\text { Darsak platform enables me to achieve } \\
\text { interaction between students. }\end{array}$ & 2.11 & 1.15 & 20 & Low \\
\hline 7 & $\begin{array}{l}\text { I can producing lessons and presenting them on } \\
\text { the Darsak platform. }\end{array}$ & 2.55 & 1.14 & 10 & Medium \\
\hline 8 & $\begin{array}{l}\text { Darsak platform helps me to evaluate students } \\
\text { in a good way. }\end{array}$ & 2.33 & 1.11 & 16 & Low \\
\hline 9 & $\begin{array}{l}\text { I Use Darsak platform to better achieve subject } \\
\text { goals. }\end{array}$ & 2.55 & 1.09 & 11 & Medium \\
\hline 10 & $\begin{array}{l}\text { Darsak platform enables me to adopt the } \\
\text { continuous evaluation of students. }\end{array}$ & 2.55 & 1.11 & 12 & Medium \\
\hline 11 & $\begin{array}{l}\text { Darsak platform helps me to stimulate the } \\
\text { different types of thinking among students. }\end{array}$ & 2.36 & 1.04 & 14 & Medium \\
\hline 12 & $\begin{array}{l}\text { Darsak platform gives me the opportunity to } \\
\text { discuss students and enrich the mutual } \\
\text { dialogue. }\end{array}$ & 2.04 & 1.05 & 21 & Low \\
\hline 14 & $\begin{array}{l}\text { Darsak platform gives students the ability to } \\
\text { ask questions. }\end{array}$ & 2.35 & 1.19 & 15 & Medium \\
Darsak platform enables me to diversify the & 2.26 & 1.07 & 17 & Low \\
\hline & & & & \\
\hline
\end{tabular}




\begin{tabular}{|c|l|c|c|c|c|}
\hline & educational situation of students. & & & \\
\hline 15 & $\begin{array}{l}\text { Darsak platform enables students to be more } \\
\text { motivated towards the lesson. }\end{array}$ & 2.25 & 1.10 & 18 & Low \\
\hline 16 & $\begin{array}{l}\text { Darsak platform enables me to encourage } \\
\text { students to self-learn }\end{array}$ & 2.73 & 1.14 & 9 & Medium \\
\hline 17 & $\begin{array}{l}\text { Darsak platform enables me to know the } \\
\text { individual differences between students. }\end{array}$ & 2.24 & 1.20 & 19 & Low \\
\hline 18 & $\begin{array}{l}\text { I possess teaching competencies through } \\
\text { Darsak platform. }\end{array}$ & 3.00 & 1.02 & 4 & Medium \\
\hline 19 & $\begin{array}{l}\text { It is difficult to know the actual attendance of } \\
\text { students on the Darsak platform. }\end{array}$ & 3.02 & 1.22 & 3 & Medium \\
\hline 20 & $\begin{array}{l}\text { Darsak platform is concerned with } \\
\text { international standards for the use of electronic } \\
\text { educational platforms. }\end{array}$ & 2.73 & 1.11 & 8 & Medium \\
\hline 21 & Darsak platform helps me to save a lot of time. & 3.31 & 1.11 & 1 & Medium \\
\hline & $\quad 2.59$ & 0.84 & & Medium \\
\hline
\end{tabular}

Table (4) shows that the arithmetic mean for the section of the teacher's using of Darsak platform in preparing electronic content and follow-up student for total grade was (2.59) and standard deviation was (0.84) with a Medium degree.

the item: " Darsak platform helps me to save a lot of time" got the highest rank, and a Medium degree, the arithmetic mean was (3.31) and standard deviation was (1.11), the item: " Darsak platform gives me the opportunity to discuss students and enrich the mutual dialogue" got the lowest level, and a low degree, the mean arithmetic was (2.04), and standard deviation was (1.05).

This result can be attributed to the opinion of the primary schools teachers on the degree to using the Darsak platform came to a Medium degree, Although the internet and computers are largely present. The reason may be the lack of facilities and equipment such as networks, devices, in many schools that encourage the application of technological skills. This showed a Medium degree of use in their responses to this study tool.

This result also can be attributed to the fact that the study sample believes that there are some concerns with the continuous use of electronic devices, This result implicitly agreed with the result of the study of Al-Maliki and Daghestani (2020), Which showed that the practice of kindergarten teachers of electronic platforms amounted to (87.2\%), The Al-Shawarbeh study (2019) also showed a difference in the degree of graduate students' use of online platforms, as it was of a high degree. While the study of AlRashidi and Brahim (2019) showed that the responses of the study sample were in agreement with a high degree of the reality of using computer parameters for electronic educational platforms in teaching.

\section{- What are the obstacles encountered by} teachers on the Darsak platform?

In answering this question, arithmetic means and standard deviations, ranks and the level for the degree of obstacles encountered by teachers on the Darsak platform, were elicited and calculated as presented in the following table:

Table (5) Arithmetic means and standard deviations of the for the items of the degree section of the "the obstacles encountered by teachers on the Darsak platform", and its total grade

\begin{tabular}{|c|c|c|c|c|c|}
\hline No. & Item & Mean & $\begin{array}{c}\text { Sta. } \\
\text { Deviation }\end{array}$ & Rank & Level \\
\hline
\end{tabular}




\begin{tabular}{|c|c|c|c|c|c|}
\hline 22 & $\begin{array}{l}\text { There are no many professionals responsible } \\
\text { for training teachers in the optimal use of the } \\
\text { platform. }\end{array}$ & 3.13 & 1.13 & 8 & Medium \\
\hline 23 & $\begin{array}{l}\text { Insufficient teacher training in the optimal use } \\
\text { of Darsak platform in advance. }\end{array}$ & 3.27 & 1.14 & 7 & Medium \\
\hline 24 & $\begin{array}{l}\text { Not receiving sufficient support in following } \\
\text { up students on the Darsak platform. }\end{array}$ & 3.03 & 1.08 & 10 & Medium \\
\hline 25 & $\begin{array}{l}\text { I do not have high competence in using the } \\
\text { Darsak platform. }\end{array}$ & 2.57 & 1.04 & 11 & Medium \\
\hline 26 & $\begin{array}{l}\text { I think that the disadvantages of the platform } \\
\text { are more than of its advantages. }\end{array}$ & 3.59 & 1.16 & 4 & Medium \\
\hline 27 & $\begin{array}{l}\text { There are some technical issues with the } \\
\text { Darsak platform. }\end{array}$ & 3.08 & 1.24 & 9 & Medium \\
\hline 28 & $\begin{array}{l}\text { Poor availability of internet networks to access } \\
\text { the Darsak platform. }\end{array}$ & 3.79 & 1.16 & 2 & High \\
\hline 29 & $\begin{array}{l}\text { The limited availability of modern devices to } \\
\text { access the Darsak platform. }\end{array}$ & 3.76 & 1.16 & 3 & High \\
\hline 30 & $\begin{array}{l}\text { The non-availability of the Darsak platform at } \\
\text { all times for free. }\end{array}$ & 3.80 & 1.20 & 1 & High \\
\hline 31 & $\begin{array}{l}\text { Lack of continuous technical and technical } \\
\text { support to address any emergency defect in the } \\
\text { platform. }\end{array}$ & 3.52 & 1.12 & 5 & Medium \\
\hline 32 & $\begin{array}{l}\text { Unable to upload all course information via the } \\
\text { Darsak platform. }\end{array}$ & 3.45 & 1.14 & 6 & Medium \\
\hline \multicolumn{2}{|r|}{ Total grade } & 3.36 & 0.79 & & Medium \\
\hline
\end{tabular}

Table (5) shows that the arithmetic mean for the section of the obstacles encountered by teachers on the Darsak platform, for total grade was (3.36) and standard deviation was (0.79) with a Medium degree.

the item: "The non-availability of the Darsak platform at all times for free" got the highest rank, and a high degree, the arithmetic mean was (3.80) and standard deviation was (1.20), and the item: " I do not have high competence in using the Darsak platform" got the lowest level, and a Medium degree, the mean arithmetic was (2.57), and standard deviation was (1.04).

The result can be attributed to There are many obstacles that affect the users of the Darsak platform, In addition to the nature of the infrastructure, as some homes or areas lack equipment that would allow the platform to be easily used Either because there is no connection to the global network, or until because computers or tablets are unavailable.

\section{- What are the obstacles encountered by the student through the Darsak platform?}

In answering this question, arithmetic means and standard deviations, ranks and the level for the degree of obstacles encountered by the student through the Darsak platform, were elicited and calculated as presented in the following table:

Table (6) Arithmetic means and standard deviations of the for the items of the degree section of the "the obstacles encountered by the student on the Darsak platform", and its total grade 


\begin{tabular}{|c|c|c|c|c|c|}
\hline No. & Item & Mean & $\begin{array}{c}\text { Sta. } \\
\text { Deviation }\end{array}$ & Rank & Level \\
\hline 33 & $\begin{array}{l}\text { It is difficult for some students to indicate their } \\
\text { actual educational level. }\end{array}$ & 3.90 & 1.02 & 13 & High \\
\hline 34 & $\begin{array}{l}\text { It is difficult for some students to communicate } \\
\text { with the teacher constantly. }\end{array}$ & 3.73 & 1.05 & 20 & High \\
\hline 35 & $\begin{array}{l}\text { The inflexibility of explaining the educational } \\
\text { material for some students. }\end{array}$ & 3.90 & 1.08 & 14 & High \\
\hline 36 & $\begin{array}{l}\text { The student complain that the lack of diversity } \\
\text { in the methods of presenting the educational } \\
\text { material. }\end{array}$ & 3.87 & 1.06 & 16 & High \\
\hline 37 & $\begin{array}{l}\text { Some students complain that the assessment is } \\
\text { limited to assessment examinations of the } \\
\text { multiple-choice type. }\end{array}$ & 3.85 & 1.10 & 17 & High \\
\hline 38 & $\begin{array}{l}\text { The Darsak platform does not allow interaction } \\
\text { between the student, educational content and } \\
\text { the teacher }\end{array}$ & 3.94 & 1.09 & 12 & High \\
\hline 39 & $\begin{array}{l}\text { There is a variation in the level of the presented } \\
\text { content due to the different style of the teacher } \\
\text { presenting the content, which is reflected on } \\
\text { the student. }\end{array}$ & 3.64 & 1.00 & 21 & Medium \\
\hline 40 & $\begin{array}{l}\text { The Darsak platform requires students to stay } \\
\text { behind screens for long periods of time. }\end{array}$ & 3.79 & 1.03 & 19 & High \\
\hline 41 & $\begin{array}{l}\text { The student is only the recipient of the } \\
\text { information on the Darsak platform. }\end{array}$ & 4.06 & 1.08 & 5 & High \\
\hline 42 & $\begin{array}{l}\text { The student does not feel the seriousness of } \\
\text { studying and distance learning remotely via the } \\
\text { Darsak platform. }\end{array}$ & 4.05 & 1.06 & 6 & High \\
\hline 43 & $\begin{array}{l}\text { The student complains about the way the } \\
\text { lessons are explained through Darsak platform, } \\
\text { which is limited to narration. }\end{array}$ & 3.98 & 1.06 & 9 & High \\
\hline 44 & $\begin{array}{l}\text { The Darsak platform does not focus on } \\
\text { individual differences between students. }\end{array}$ & 3.97 & 1.11 & 11 & High \\
\hline 45 & $\begin{array}{l}\text { The student complains about the absence of } \\
\text { visual interaction between the teacher and the } \\
\text { student on the platform. }\end{array}$ & 3.98 & 1.16 & 10 & High \\
\hline 46 & $\begin{array}{l}\text { Some students complain about deficiencies in } \\
\text { the organizing infrastructure of the lesson } \\
\text { platform. }\end{array}$ & 3.90 & 1.05 & 15 & High \\
\hline 47 & $\begin{array}{l}\text { Some students complain that they do not have } \\
\text { their own electronic device. }\end{array}$ & 4.18 & 1.07 & 2 & High \\
\hline 48 & $\begin{array}{l}\text { Some students complain about the cooperation } \\
\text { of a number of members of the same family on } \\
\text { the same device, which reduces their } \\
\text { opportunity to communicate with the Darsak }\end{array}$ & 4.20 & 1.07 & 1 & High \\
\hline
\end{tabular}




\begin{tabular}{|c|l|c|c|c|c|}
\hline & platform. & & & \\
\hline 49 & $\begin{array}{l}\text { Some students complain that the Internet is not } \\
\text { constantly available. }\end{array}$ & 4.16 & 1.00 & 3 & High \\
\hline 50 & $\begin{array}{l}\text { Darsak platform imposes more burden on the } \\
\text { student and their family. }\end{array}$ & 4.09 & 1.13 & 4 & High \\
\hline 51 & $\begin{array}{l}\text { It is difficult for some students to upload large } \\
\text { assignments and videos through the platform. }\end{array}$ & 4.02 & 1.12 & 7 & High \\
\hline 52 & $\begin{array}{l}\text { Young students complain about dealing with } \\
\text { technology efficiently. }\end{array}$ & 3.99 & 1.11 & 8 & High \\
\hline 53 & $\begin{array}{l}\text { Darsak platform does not focus on students } \\
\text { with special needs. }\end{array}$ & 3.85 & 1.21 & 18 & High \\
\hline & \multicolumn{1}{|l}{ Total grade } & 3.95 & 0.87 & & High \\
\hline
\end{tabular}

Table (6) shows that the arithmetic mean for the section of "the obstacles encountered by the student on the Darsak platform, for total grade was (3.95) and standard deviation was (0.87) with a High degree.

the item: "Some students complain about the cooperation of a number of members of the same family on the same device, which reduces their opportunity to communicate with the Darsak platform" got the highest rank, and a high degree, the arithmetic mean was (4.20) and standard deviation was (1.07), and the item: " There is a variation in the level of the presented content due to the different style of the teacher presenting the content, which is reflected on the student" got the lowest level, and a Medium degree, the mean arithmetic was (3.64), and standard deviation was (1.00).

This result may be attributed to a set of obstacles that affect students' use of the platform, which were observed by the members of the study sample. This could be due to the nature of the infrastructure, May be there are some homes or areas that do not have the equipment that allows the platform to be used easily, either because of the absence of a connection to the global network, as well as the absence of computers or tablets, This result is consistent with the result of the study of Al-Maliki and Daghestani (2020), which concluded that there are obstacles in the use of parameters for electronic platforms amounting to $(78.2 \%)$. It was also similar to the result of the study Al-Shareef (2020) which indicated that there is a high speed of the impact of the Corona virus on the education system, because the traditional method of education has been retreated to spread instead of distance learning via the Internet, and the study demonstrated the importance of using various strategies to further improve education through the Internet.

It was similar to the result of the study of Al-Rashidi and brahim (2019), which showed that the most prominent obstacles that computer teachers notice in using electronic educational platforms in teaching are the obstacles related to school administration, followed by the obstacles related to the educational material, then those related to teachers, and finally the obstacles related to female students. And Al-Dossary (2016) study, which clarified that the barriers to teachers' use of electronic educational platforms were also medium.

\section{Question two: Are there statistically significant differences at $(\alpha \leq 0.05)$ in the reality of teachers 'use of a Darsak platform in schools in southern Amman through Covied-19 due to variables (gender, experience, teacher taking courses)?}

In answering this question, Test conducted ( 3 way ANOVA), and the next table explained the arithmetic means and standard deviations for the reality of teachers 'use of a Darsak platform is related to variables (gender, experience, taking teacher courses): 
Table (7) arithmetic means and standard deviations for the reality of teachers 'use of a Darsak platform is related to variables (gender, experience, taking teacher courses)

\begin{tabular}{|c|c|c|c|c|c|c|c|c|c|c|}
\hline & \multirow[t]{3}{*}{ Gender } & \multirow{3}{*}{$\begin{array}{l}\text { taking } \\
\text { teacher } \\
\text { courses }\end{array}$} & \multicolumn{8}{|c|}{ Experience } \\
\hline & & & \multicolumn{2}{|c|}{ Less than 5 years } & \multicolumn{2}{|c|}{$(5-10)$ years } & \multicolumn{2}{|c|}{$\begin{array}{c}\text { More than } 10 \\
\text { years }\end{array}$} & \multicolumn{2}{|c|}{ Total } \\
\hline & & & Mean & $\begin{array}{l}\text { Sta. } \\
\text { Deviatio } \\
n\end{array}$ & $\begin{array}{l}\text { Mea } \\
\mathrm{n}\end{array}$ & $\begin{array}{l}\text { Sta. } \\
\text { Deviatio } \\
\text { n }\end{array}$ & $\begin{array}{l}\text { Mea } \\
\mathrm{n}\end{array}$ & $\begin{array}{l}\text { Sta. } \\
\text { Deviatio } \\
n\end{array}$ & $\begin{array}{l}\text { Mea } \\
n\end{array}$ & $\begin{array}{l}\text { Sta. } \\
\text { Deviatio } \\
\mathrm{n}\end{array}$ \\
\hline \multirow{9}{*}{$\begin{array}{l}\text { the degree } \\
\text { of } \\
\text { teacher's } \\
\text { using of } \\
\text { Darsak } \\
\text { platform } \\
\text { in } \\
\text { preparing } \\
\text { electronic } \\
\text { content } \\
\text { and } \\
\text { follow-up } \\
\text { students }\end{array}$} & \multirow[t]{3}{*}{ Male } & No & 2.80 & 1.04 & 2.57 & 0.84 & 0.98 & 0.55 & 2.55 & 0.93 \\
\hline & & Yes & 2.93 & 0.65 & 2.47 & 0.75 & 2.23 & 0.81 & 2.48 & 0.78 \\
\hline & & Total & 2.84 & 0.93 & 2.53 & 0.78 & 2.21 & 0.75 & 2.52 & 0.86 \\
\hline & \multirow[t]{3}{*}{ Female } & No & 2.68 & 0.77 & 3.05 & 0.69 & 2.48 & 1.08 & 2.72 & 0.78 \\
\hline & & Yes & 2.99 & 0.77 & 2.17 & 0.87 & 2.82 & 0.75 & 2.69 & 0.84 \\
\hline & & Total & 2.82 & 0.77 & 2.41 & 0.90 & 2.76 & 0.78 & 2.70 & 0.81 \\
\hline & \multirow[t]{3}{*}{ Total } & No & 2.75 & 0.92 & 2.68 & 0.81 & 2.10 & 0.69 & 2.61 & 0.88 \\
\hline & & Yes & 2.97 & 0.71 & 2.32 & 0.81 & 2.51 & 0.82 & 2.58 & 0.82 \\
\hline & & Total & 2.83 & 0.85 & 2.48 & 0.82 & 2.41 & 0.80 & 2.59 & 0.84 \\
\hline \multirow{9}{*}{$\begin{array}{l}\text { obstacles } \\
\text { encounter } \\
\text { ed by } \\
\text { teachers } \\
\text { on the } \\
\text { Darsak } \\
\text { platform }\end{array}$} & \multirow[t]{3}{*}{ Male } & No & 3.35 & 1.08 & 3.34 & 1.14 & 3.85 & 0.78 & 3.45 & 1.04 \\
\hline & & Yes & 3.11 & 0.99 & 3.32 & 0.51 & 3.60 & 0.67 & 3.43 & 0.72 \\
\hline & & Total & 3.28 & 1.04 & 3.33 & 0.89 & 3.67 & 0.70 & 3.44 & 0.89 \\
\hline & \multirow[t]{3}{*}{ Female } & No & 3.07 & 0.38 & 3.57 & 0.75 & 3.06 & 0.60 & 3.15 & 0.49 \\
\hline & & Yes & 3.34 & 0.63 & 3.32 & 0.92 & 3.33 & 0.63 & 3.33 & 0.70 \\
\hline & & Total & 3.19 & 0.52 & 3.39 & 0.86 & 3.28 & 0.61 & 3.27 & 0.63 \\
\hline & \multirow[t]{3}{*}{ Total } & No & 3.22 & 0.85 & 3.39 & 1.05 & 3.65 & 0.79 & 3.35 & 0.89 \\
\hline & & Yes & 3.26 & 0.77 & 3.32 & 0.72 & 3.49 & 0.66 & 3.38 & 0.71 \\
\hline & & Total & 3.23 & 0.81 & 3.35 & 0.87 & 3.53 & 0.69 & 3.36 & 0.79 \\
\hline \multirow{9}{*}{$\begin{array}{l}\text { obstacles } \\
\text { encounter } \\
\text { ed by the } \\
\text { students } \\
\text { on the } \\
\text { Darsak } \\
\text { platform }\end{array}$} & \multirow[t]{3}{*}{ Male } & No & 3.65 & 0.98 & 3.83 & 1.22 & 4.41 & 0.76 & 3.87 & 1.04 \\
\hline & & Yes & 3.86 & 0.30 & 3.94 & 0.88 & 4.31 & 0.72 & 4.12 & 0.72 \\
\hline & & Total & 3.71 & 0.84 & 3.88 & 1.06 & 4.34 & 0.72 & 3.99 & 0.90 \\
\hline & \multirow[t]{3}{*}{ Female } & No & 3.82 & 0.76 & 4.03 & 0.76 & 4.46 & 0.41 & 3.94 & 0.73 \\
\hline & & Yes & 3.94 & 0.55 & 3.87 & 1.29 & 3.86 & 0.90 & 3.89 & 0.91 \\
\hline & & Total & 3.87 & 0.67 & 3.91 & 1.14 & 3.96 & 0.86 & 3.91 & 0.84 \\
\hline & \multirow[t]{3}{*}{ Total } & No & 3.72 & 0.88 & 3.87 & 1.11 & 4.43 & 0.67 & 3.89 & 0.94 \\
\hline & & Yes & 3.91 & 0.47 & 3.90 & 1.08 & 4.13 & 0.81 & 4.01 & 0.82 \\
\hline & & Total & 3.79 & 0.75 & 3.89 & 1.08 & 4.20 & 0.78 & 3.95 & 0.87 \\
\hline
\end{tabular}

Table (7) shows that there are differences in the arithmetic means for the variables (gender, experience, taking teacher courses), and to determine whether the differences between the arithmetic averages statistically significant at the level of significance $(\alpha \leq 0.05) 3$ - Way ANOVA was used as presented in the following Table: 
Table (8) 3-way ANOVA analysis for the determine the differences between the effect of the variables (gender, experience, taking teacher courses), in the reality sections of using Darsak platform

\begin{tabular}{|c|c|c|c|c|c|c|c|}
\hline Source & No. & Dependent variables & $\begin{array}{c}\text { Square } \\
\text { Total }\end{array}$ & $\begin{array}{l}\text { Degree of } \\
\text { Freedom }\end{array}$ & $\begin{array}{c}\text { Square } \\
\text { mean }\end{array}$ & $\begin{array}{c}\text { "F" } \\
\text { Value }\end{array}$ & $\begin{array}{c}\text { Statistical } \\
\text { significance }\end{array}$ \\
\hline \multirow{3}{*}{$\begin{array}{c}\text { gender } \\
\text { Wilkes } \\
\text { lambda }=(\mathrm{s} \\
=0.97, \mathrm{q}= \\
1.75, \mathrm{dh}=5)\end{array}$} & 1 & $\begin{array}{l}\text { teacher's using of } \\
\text { Darsak platform }\end{array}$ & 4.783 & 2 & 2.391 & 3.394 & 0.03 \\
\hline & 2 & $\begin{array}{c}\text { obstacles encountered } \\
\text { by teachers }\end{array}$ & 1.861 & 2 & 0.930 & 1.481 & 0.23 \\
\hline & 3 & $\begin{array}{l}\text { obstacles encountered } \\
\text { by the students }\end{array}$ & 3.843 & 2 & 1.922 & 2.552 & 0.08 \\
\hline \multirow{3}{*}{$\begin{array}{c}\text { Experience } \\
\text { Wilkes } \\
\text { lambda }(\mathrm{s}= \\
0.96, \mathrm{q}= \\
1.25, \mathrm{dh}=5)\end{array}$} & 1 & $\begin{array}{l}\text { teacher's using of } \\
\text { Darsak platform }\end{array}$ & 0.471 & 1 & 0.471 & 0.688 & 0.41 \\
\hline & 2 & $\begin{array}{c}\text { obstacles encountered } \\
\text { by teachers }\end{array}$ & 0.651 & 1 & 0.651 & 1.036 & 0.31 \\
\hline & 3 & $\begin{array}{l}\text { obstacles encountered } \\
\text { by the students }\end{array}$ & 0.065 & 1 & 0.065 & 0.086 & 0.77 \\
\hline \multirow{3}{*}{$\begin{array}{c}\text { taking } \\
\text { teacher } \\
\text { courses } \\
\text { Wilkes } \\
\text { lambda (s = } \\
0.96, \mathrm{q}= \\
1.25, \mathrm{dh}=5)\end{array}$} & 1 & $\begin{array}{l}\text { teacher's using of } \\
\text { Darsak platform }\end{array}$ & 0.170 & 1 & 0.170 & 0.248 & 0.62 \\
\hline & 2 & $\begin{array}{c}\text { obstacles encountered } \\
\text { by teachers }\end{array}$ & 0.018 & 1 & 0.018 & 0.028 & 0.87 \\
\hline & 3 & $\begin{array}{l}\text { obstacles encountered } \\
\text { by the students }\end{array}$ & 0.005 & 1 & 0.005 & 0.006 & 0.94 \\
\hline \multirow[t]{3}{*}{ Error } & 1 & $\begin{array}{l}\text { teacher's using of } \\
\text { Darsak platform }\end{array}$ & 94.444 & 138 & 0.684 & & \\
\hline & 2 & $\begin{array}{c}\text { obstacles encountered } \\
\text { by teachers }\end{array}$ & 86.709 & 138 & 0.628 & & \\
\hline & 3 & $\begin{array}{l}\text { obstacles encountered } \\
\text { by the students }\end{array}$ & 103.915 & 138 & 0.753 & & \\
\hline \multirow[t]{3}{*}{$\begin{array}{c}\text { Total } \\
\text { average }\end{array}$} & 1 & $\begin{array}{l}\text { teacher's using of } \\
\text { Darsak platform }\end{array}$ & 100.513 & 142 & & & \\
\hline & 2 & $\begin{array}{c}\text { obstacles encountered } \\
\text { by teachers }\end{array}$ & 89.744 & 142 & & & \\
\hline & 3 & $\begin{array}{l}\text { obstacles encountered } \\
\text { by the students }\end{array}$ & 108.555 & 142 & & & \\
\hline
\end{tabular}

* Statistically significant at the level of significance $(\alpha=0.05)$

Table (8) shows that there are differences in the Statistically significant at the level of significance $(\alpha=0.05)$ in the teacher's using of Darsak platform in preparing electronic content and follow-up students and in the obstacles encountered by the student on the Darsak platform from teachers point of view related to Experience variable, and to determine the differences between the groups The Tuki test was performed for the dimensional comparisons as shown in the table (9). 
Table (9) Toki test results to determine the significance of differences according to Experience in the sections of reality of using Darsak platform of first and third section

\begin{tabular}{|c|c|c|c|c|c|}
\hline Section & Level & Other levels & $\begin{array}{c}\text { Average } \\
\text { difference }\end{array}$ & $\begin{array}{c}\text { Standard } \\
\text { error }\end{array}$ & $\begin{array}{c}\text { Statistical } \\
\text { significance }\end{array}$ \\
\hline \multirow[t]{3}{*}{ First } & $\begin{array}{l}\text { Less than } 5 \\
\text { years }\end{array}$ & $(5-10)$ years & 0.3491 & 0.17159 & 0.11 \\
\hline & & $\begin{array}{l}\text { More than } 10 \\
\text { years }\end{array}$ & 0.4218 & 0.16269 & 0.03 \\
\hline & (5-10) years & $\begin{array}{l}\text { More than } 10 \\
\text { years }\end{array}$ & 0.0727 & 0.17885 & 0.91 \\
\hline \multirow[t]{3}{*}{ Third } & $\begin{array}{l}\text { Less than } 5 \\
\text { years }\end{array}$ & (5-10) years & -0.1181 & 0.16504 & 0.45 \\
\hline & & $\begin{array}{l}\text { More than } 10 \\
\text { years }\end{array}$ & -0.2983 & 0.15648 & 0.14 \\
\hline & (5-10) years & $\begin{array}{l}\text { More than } 10 \\
\text { years }\end{array}$ & -0.1802 & 0.17203 & 0.55 \\
\hline
\end{tabular}

Table (9) shows that there are differences in the Statistically significant at the level of significance $(\alpha=0.05)$ in the teacher's using of Darsak platform in preparing electronic content and follow-up students according to Experience variable Where differences emerged between teachers with less than 5 years of experience the arithmetic mean was (2.83), and teachers with more than 10 years of experience the arithmetic mean was (2.41), that teachers with less than 5 years of experience have outperformed.

The result may be attributed to the fact that teachers with short experience are the teachers who experienced the technology more and use it more than other groups, which was reflected in their view, which came to be the most use of Darsak platform.

Table (9) also shows that there are differences in the Statistically significant at the level of significance $(\alpha=0.05)$ in the obstacles encountered by the students at Darsak platform from teachers point of view related to experience variable Where differences emerged between teachers with less than 5 years of experience the arithmetic mean was (3.79), and teachers with more than 10 years of experience the arithmetic mean was (4.20), that teachers with more than 10 years of experience have outperformed to the obstacles encountered by the students at Darsak platform than other teachers.

The result may be attributed to the fact that teachers with long experience do not prefer the practice of technology reflected on their point of view regarding the students and the obstacles they suffer that prevent them from using Darsak platform easily.

While there were no statistically significant differences for the gender variable; This result can be explained by the fact that male and female teachers are exposed to almost the same conditions and environments, in addition to the surrounding influences that are usually similar, They get the same training courses because they belong to the same educational institutions. This result differed with the result of the Sharif study (2020), which indicated the existence of statistically significant differences due to the effect of gender, was for males.

The result also indicated that there was no statistically significant difference at the level of significance $(\alpha=0.05)$ in the arithmetic means for the variable (taking teacher courses in computer) which means the The reality of using the lesson platform is their one point of view without concern about their taking computer courses, given that everyone routinely uses technology and 
platforms.

\section{Recommendations}

From the results, the study recommends the following:

- Encouraging primary school teachers on the necessity of using Darsak platform at a wide level.

- Educating people about the importance of e-learning, by holding seminars and publishing brochures containing the benefits of e-learning.

- To benefit from the experiences of developed countries in the section of elearning.

- Improving the infrastructure that serves communications.

- Holding courses and workshops that help primary school teachers acquire the necessary skills to use Darsak platform.

\section{References}

[1] A guide for using the distance learning platform "Darsak" (2020), retrieved on 10/30/2020 http //: www.moe.gov.jo

[2] Abdel-Naim, Radwan (2016). Educational platforms. Amman: Dar Al Uloom for Publishing and Distribution.

[3] Adeniran, A. (2020). Ensuring Learning continuity for every African child in the time of COVED-19. Retrieved https://www.brookings.edu/blog/education -plus-development/2020/06/04/

[4] Al-Maliki, A. (2010). A Research to Implement Blended Learning in Saudi Universities: A University, China.

[5] Al-Anezi, Youssef (2017). Effective use of educational platforms (Edmodo) for major students Mathematics and computer at the College of Islamic Education in the State of Kuwait. Scientific Journal of the College of Education, 33 (6): 192-241.

[6] Al-Dossary, Muhammad (2016). The reality of faculty members' use of electronic educational platforms in teaching English at King Saud University. Unpublished master theory, Yarmouk University, Irbid, Jordan.

[7] Al-Juhani, Lily (2016). Investigating the behavioral intentions of graduate students to use the Adamudu platform In the future, using the Technology Acceptance Form, Journal of the College of Basic Education for Sciences Educational and Humanitarian, University of Babylon, (28), 68-90.

[8] Al-Maliki, Haifa'a \& Daghestani, Balqees (2020). The Role of E-Learning Platforms in the Professional Development of Kindergarten Teachers. The Educational Journal, 73: 1127-1156.

[9] Al-raghbi, M.(2019). "Use of massive open online courses (MOOCS) in the professional development of science teachers Jeddah". "In Arabic"

[10] Al-Rashidi, Mounira \& Brahim, Amal (2019). The reality of using computer parameters for educational platforms Electronic teaching and their attitudes towards it. Journal of Scientific Research in Education, 20 (3): 1-26.

[11] Al-Shareef, Basem (2020). The reality of university students' attitudes towards employing digital platforms in university education Kingdom of Saudi Arabia (Taibah University Model). Taibah University Journal of Arts and Humanities, 22: 352-406.

[12] AL-Shawarbeh, Dalieh (2019). The degree of employment of graduate students in private Jordanian universities E-learning platforms and their attitudes towards them. Unpublished MA Thesis, University Middle East, Jordan.

[13] Anderson, T. (2008). The Theory and Practice of Online. AU Press, Athabasca University, Japan.

[14] Bayeck, R. (2016). Exploratory study of 
MOOCs learners 'demographics and motivation: The case of students involved in groups, Open PRAXIS, International Council for open and distance education, 8 (3):33-45.

[15] Bedir, H. (2019). Pre-service ELT teachers' beliefs and perceptions on 21 st century learning and innovation skills (4Cs). Journal of Language and Linguistic Studies, 15 (1), 231-246.

[16] Bozkurt et al., (2020). A global outlook to the interruption of education due to COVID- 19 Pandemic: Navigating in a time of uncertainty and crisis. Asian Journal of Distance Education, 15 (1), 126.

[17] Buzzetto, M. (2012). Special Section on Social Networking, Teaching, and Learning Social Networking in Undergraduate Education Interdisciplinary, Journal of Information, Knowledge, and Management, 7: 63-90.

[18] Carlos, J\& Infante, A. (2015). Social Learning Environments International Conference on Interactive Collaborative Learning (ICL), Florence, Italy.

[19] Caruth, G. (2013). Distance Education in the United States: from Correspondence Coerces to the Internet. Turkish Online Journal of Distance Education, 14 (2): 28.

[20] Christopher, J., (2020). Coronavirus and challenging times for education in developing countries. Retrieved https://www.brookings.edu/blog/educatio n-plus- development.

[21] David, Murphy, D., Slovak, P., Thieme, A., Jackson, D., Olivier, P. \& Fitzpatrick, G. (2019). Developing Technology to Enhance Learning Interpersonal Skills in Counsellor Education. British Journal of Guidance \& Counselling, 47(3): 328-341.

[22] Distance learning system (2020). Retrieved on 10/30/2020 from the site http //: www.moe.gov.jo.
[23] Durak, G. (2017). Trends in Distance Education: A Content Analysis of Master's Thesis. The Turkish Online Journal of Education Technology, 16 (1): 203-218.

[24] Elis, R. \& Goodyear, P. (2010). Students' Experience of e- learning in higher education: The ecology of Sustainable Innovation. Florence, KY: Routledge.

[25] Farah, M. (2015). A study of Students' Interaction, Envisioning the Future of Online Learning Selected Papers from the International Conference on e-Learning, 147-158.

[26] Gill, D (2019). A Technology Education Teaching Framework: Factors That Support and Hinder Intermediate Technology Education Teachers, International Journal of Technology and Design Education, 29(4): 669-684.

[27] Huang, S. (2008). The relationship between computer use and academic achievements. Unpublished $\mathrm{PhD}$ thesis, University of North Texas. USA.

[28] Ibrahim, N., Adzra'ai, A., Sueb, R., \& Dalim, S. F. (2019). Trainee Teachers' Readiness towards 21st Century Teaching Practices. Asian Journal of University Education, 15 (1), 20-29

[29] Martirosyan, N., Kennon, J., Lindesry, S. Patrik, E., Edmonson, S. \& Susan, T. (2017). Instructional Technology Practices in Developmental Educations in Texas, Journal of College Reading and Learning, 47(1): 3-25.

[30] Mujahid, Faiza (2020). E-Learning in the Time of Coronavirus: Prospects and Hopes. International Journal of Research in Educational Sciences, 3 (4): 305-335.

[31] Parekh, R. (2006). Principles of multimedia. New Delhr: Tata McGrawHill Education.

[32] Saini, R. (2014) A Flash Back ON COMPUTER ASSISTED INSTRUCTION (CAI), Research Directions Journal, 1(7) 
$1-10$

[33] Singh, Y., \& Upadhya, B. (2008). Education Technology: teaching Learning. New Delhr: APH Puplishing.

[34] Unesco Education (2020). From Disruption to recovery, Retrieved https://en.unesco.org/covid19/educationres ponse.

[35] Warner, C., Bell, C., \& Odom, A. (2018). Defining Technology for Learning: Cognitive and Physical Tools of Inquiry Middle Grades Review, 4(1). 12-25.

[36] Yang, D., Baldwin, S. (2020). Using Technology to Support Student Learning in an Integrated STEM. Learning Environment, International Journal of Technology in Education and Science, 4(1): 1-11.

[37] Zhang, M. (2017). Influence of Customer Engagement with Company Social Networks on Stickiness: Mediating Effect of Customer Value Creation, International Journal of Information Management, 37(3): 229-240. 